\title{
Surface ozone depletion episodes in the Arctic and Antarctic from historical ozonesonde records
}

\author{
D. W. Tarasick and J. W. Bottenheim \\ Environment Canada, 4905 Dufferin Street, Downsview, ON, M3H 5T4 Canada \\ Received: 5 March 2002 - Published in Atmos. Chem. Phys. Discuss.: 27 March 2002 \\ Revised: 23 July 2002 - Accepted: 30 July 2002 - Published: 8 August 2002
}

\begin{abstract}
Episodes of ozone depletion in the lowermost Arctic atmosphere $(0-2 \mathrm{~km})$ at polar sunrise have been intensively studied at Alert, Canada, and are thought to result from catalytic reactions involving bromine. Recent observations of high concentrations of tropospheric $\mathrm{BrO}$ over large areas of the Arctic and Antarctic suggest that such depletion events should also be seen by ozonesondes at other polar stations. An examination of historical ozonesonde records shows that such events occur frequently at Alert, Eureka and Resolute, but much less frequently at Churchill and at other stations. The differences appear to be related to differences in average springtime surface temperatures. The long record at Resolute shows depletions since 1966, but with an increase in their frequency over the period $1966-2000$ of $0.66 \pm 0.59 \%$ per year (95\% confidence limits), explaining the apparent increase of $\mathrm{Hg}$ in Arctic biota in recent times.
\end{abstract}

\section{Introduction}

Observations of anomalously low ozone at the surface in the Arctic spring have been reported by several authors (Bottenheim et al., 1986; Oltmans and Kohmyr, 1986; Anlauf et al., 1994) and are thought to be caused by catalytic reactions involving reactive halogen atoms, especially bromine, originating in the polar ocean (Barrie et al., 1988; Barrie and Platt, 1997). The reaction of bromine with ozone yields $\mathrm{BrO}$, so that the presence of tropospheric $\mathrm{BrO}$ should be an indicator of ozone depletion. Recent aircraft and satellite observations indicate that significant amounts of $\mathrm{BrO}$ are found in the lower troposphere over a large area of the Arctic at polar sunrise (McElroy et al., 1999; Richter et al., 1998; Wagner and Platt, 1998). In particular Richter et al. (1998) find a large area of enhanced $\mathrm{BrO}$ centred over Hudson Bay, north

Correspondence to: D. W. Tarasick

(david.tarasick@ec.gc.ca) of Churchill, Canada. Images from the GOME instrument aboard ERS-2 also show BrO in the Antarctic, near the edges of the polar continent. This suggests that boundary-layer depletions should be widespread and common, and therefore might be observable from ozonesonde records at a number of Canadian and other sites.

In addition to the extensive observations at Alert $(83 \mathrm{~N}$, $62 \mathrm{~W}$ ), such events have in fact previously been reported (primarily in surface data) for Barrow, Alaska $(71 \mathrm{~N}, 157 \mathrm{~W})$ (Oltmans and Kohmyr, 1986), Ny-Ålesund (79 N, 12 E) and Bear Island $(74 \mathrm{~N}, 19 \mathrm{E})$ in the Norwegian Arctic (Solberg et al., 1996), Thule (77 N, 69 W) and Søndre Strømfjord $(67 \mathrm{~N}, 51 \mathrm{~W})$ in Greenland (Rasmussen et al., 1997; Miller et al., 1997), as well as Marambio (64 S, $57 \mathrm{~W}$ ) (Taalas et al., 1993), Neumayer (71 S, 8 W) (Wessel et al., 1998), and apparently Syowa (69 S, 40 E) (Murayama et al., 1992), in the Antarctic. In general these have been studied as individual events, or (usually short) time series of surface measurements. For this reason little is known about how frequently they occur, or have occurred in the past, at different locations in the Arctic and Antarctic. The ozonesonde record for a number of stations, particularly in Canada (where sondes have been launched regularly since 1966) offers a unique opportunity to examine several time series of this interesting phenomenon, with measurements that are both long-term, and vertically-resolved.

\section{Recent observations from the Canadian network}

Figure 1 shows examples of depletion events observed recently at three Canadian ozonesonde stations: Eureka (80 N, $86 \mathrm{~W})$, Resolute (75 N, $95 \mathrm{~W}$ ) and Churchill (59 N, $94 \mathrm{~W})$. Like Alert, all three stations are near polar sea ice and are close to or within the area of maximum $\mathrm{BrO}$ concentration found in March and April in the GOME dataset. These examples illustrate a number of features of these events: de- 

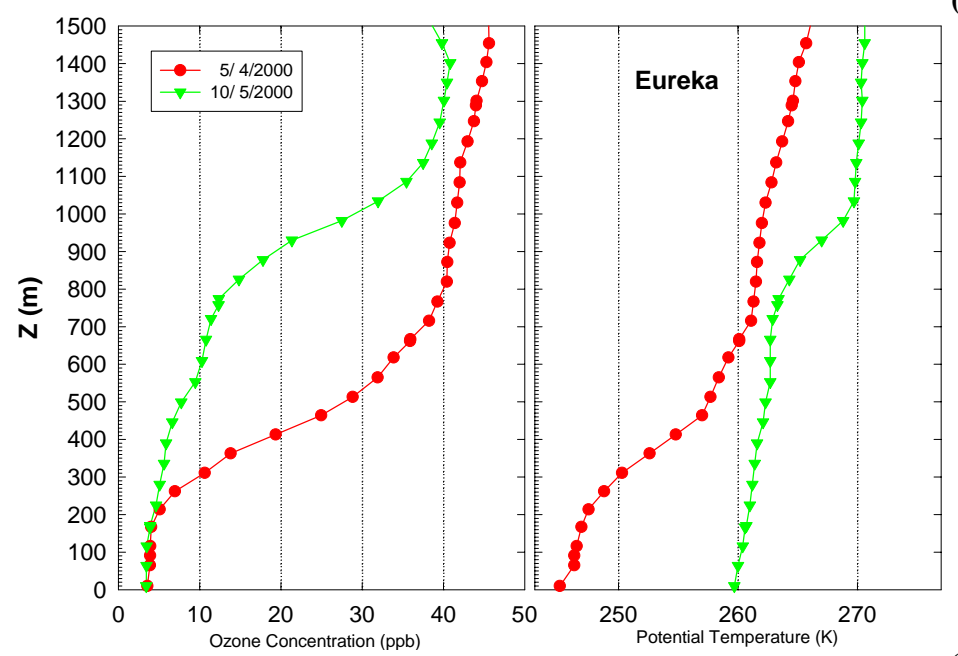

(a)
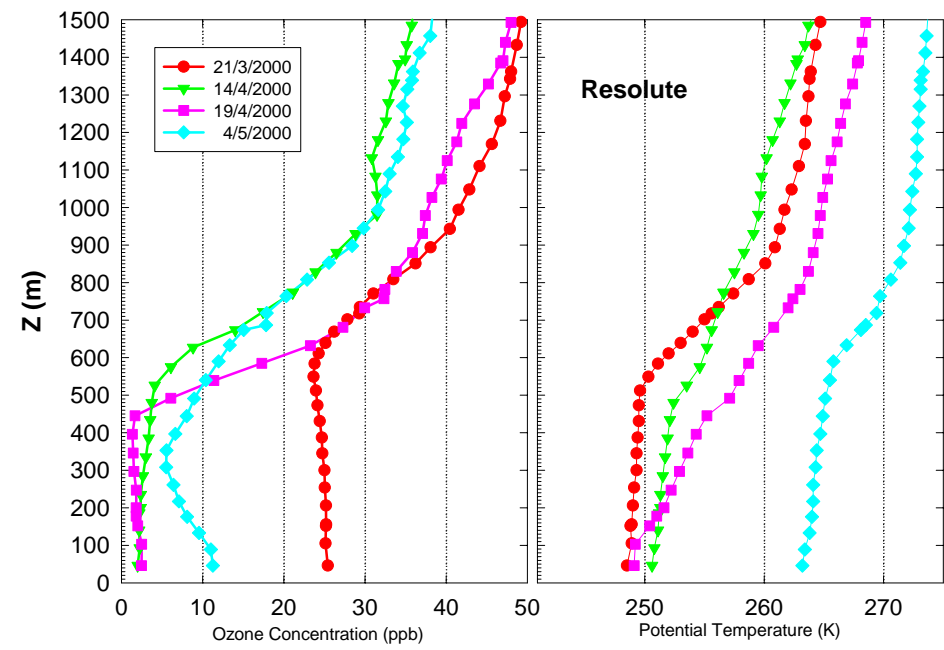

(b)

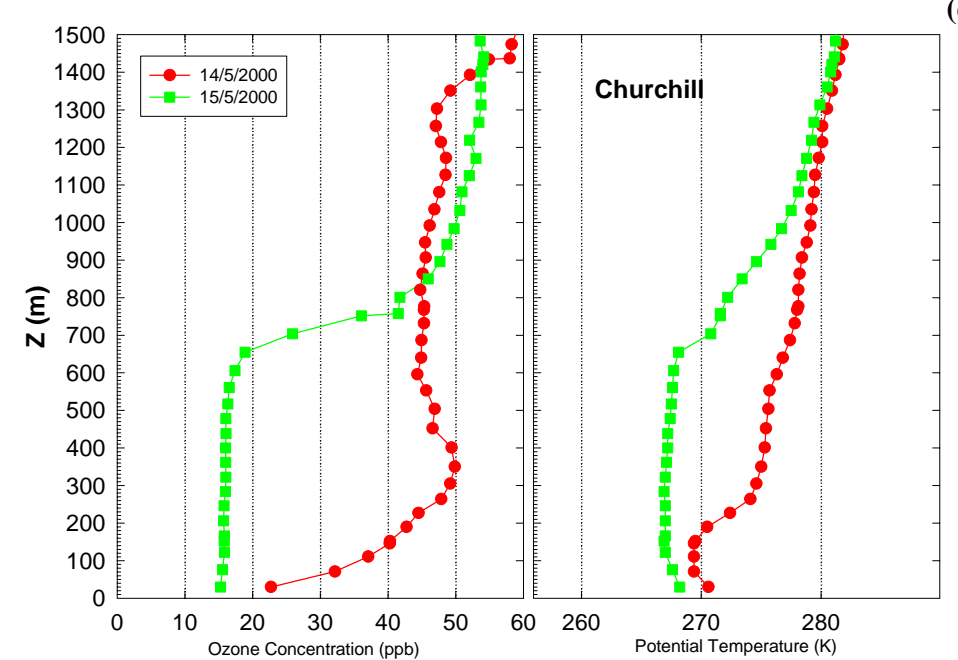

(c)

Fig. 1. (a) Recent surface ozone depletion events at Eureka, Canada, from regular ozone soundings. (b) Recent surface ozone depletion events at Resolute, Canada. (c) Recent (partial) surface depletion events at Churchill, Canada. Note that in most cases the depleted layer is capped by an inversion layer (layer of strongly positive potential temperature gradient, shown on the right of the figure). 
pletions can be partial (Fig. 1c) or complete (Fig. 1b), where the ozone drops below measurable levels $(\sim 1 \mathrm{ppb})$; they are generally associated with an inversion layer (layer of strongly positive potential temperature gradient, shown on the right of each figure); in vertical extent they can be from less than $100 \mathrm{~m}$ to more than $1 \mathrm{~km}$; they are observed in the Arctic almost exclusively in March, April and May.

\section{Historical data from Canadian and other stations}

While the high resolution data in Fig. 1 is available only for the last few years, there is a much larger archive of lower resolution data. The effective resolution of these data is much better than might be apparent, as the older sondes actually made an ozone measurement every $15-20 \mathrm{~s}$, a frequency comparable to the 10-s measurements that are currently archived. This was recorded mechanically and reduced by hand, the operator recording all inflections in the profile considered significant (points whose omission would induce an error in the reconstructed profile greater than $\sim 2 \%$ ). This is more properly regarded as a "data compression" technique (to use modern terminology) than a low-resolution transcription. Events like those in Fig. 1 should therefore be clearly captured in the older record. This is easily verified, as the older format is still routinely produced for Canadian flights. Figure 2 shows the same soundings as in the previous figure, but in the older format. While the nominal resolution of these profiles is lower than of Fig. 1, the effective resolution is clearly adequate to identify both the degree of depletion and the vertical extent of the depleted layer and the accompanying temperature inversion.

The soundings in the preceding figures were all made with ECC sondes. Before 1980 the Canadian network used Brewer-Mast (BM) sondes, which are believed to have had a negative bias in the troposphere, as well as a greater frequency of sonde malfunction. Despite these deficiencies, the Brewer-Mast record also clearly shows these events. Figure 3, from May, 1969, shows what appears to be a twolayer depletion, a strong depletion from the surface to about $250 \mathrm{~m}$, with a weaker one above it, extending to about $2 \mathrm{~km}$ in height.

Depletions are in fact sufficiently frequent and persistent at Resolute, Eureka and Alert that average surface ozone there shows a springtime minimum, even though ozone in the middle and upper troposphere at these stations has an annual maximum in May (Tarasick et al., 1995). In addition, the Canadian ozonesonde record is quite extensive, and regular: sondes are flown weekly at Canadian stations, with additional flights during times of special interest, like the Arctic spring. This makes it possible to examine the climatology of these events.

A number of other ozonesonde stations are also situated where they might be expected to experience frequent surface depletion episodes: Ny-Ålesund, Bear Island, Thule and
Scoresbysund (71 N, $22 \mathrm{~W})$ in the Arctic, as well as Syowa, Marambio and Neumayer in the Antarctic. We examined ozonesonde records for these stations as well. Only a few years of data were available to us for Bear Island (19935), Thule (1994-6; March 2000) and Scoresbysund (1994-7; March 1999, 2000); we found two events at Thule and none at Bear Island or Scoresbysund.

Syowa, Neumayer and Marambio are close to polar ice and to areas where the GOME instrument shows high $\mathrm{BrO}$ concentrations around the Antarctic continent in the SeptemberNovember period of Antarctic spring. The Syowa record is also very long, beginning in 1966 . Unfortunately the data resolution in the troposphere is very low (only standard levels are reported), making the unambiguous detection of depletion events difficult. Sondes are also of a different type (carbon-iodine). No events were found at Syowa. However, the other three stations (Ny-Ålesund, Marambio and Neumayer) have sufficient resolution and long enough records for several unambiguous examples of depletion events to be detected in each case.

In order to permit quantitative analysis, for the purpose of this paper we will define an ozone surface depletion event as an occurrence where $\left[\mathrm{O}_{3}\right]<10 \mathrm{ppbv}$ at the surface and first recorded level. This is a relatively severe criterion: it excludes partial depletions such as those in Fig. 1c. It is 50\% below the seasonal minimum of the climatologically average ozone mixing ratio of about $20 \mathrm{ppbv}$ which usually occurs in mid to late summer (e.g. Oltmans and Kohmyr, 1986; Anlauf et al., 1999) and hence has the benefit of screening out soundings that are not representative of true halogen-driven ozone depletions. More relaxed selection criteria (15 and $20 \mathrm{ppb}$ ) were also tried; while admitting more (partial) depletion events like those in Figs. $1 \mathrm{~b}$ and c, they also (incorrectly) identified as depletion events many soundings outside the spring period, in particular many normal summer profiles.

The data set employed consists of all ECC flights, without total ozone correction, and all Brewer-Mast flights with total ozone correction factors between 0.8 and 1.6. BrewerMast data were also corrected for a known bias in the troposphere (Tarasick et al., 2002). This correction increased ozone values in the lower troposphere by $15 \%$. Results varied only slightly when this bias correction was omitted, or when all BM flights were included, or total ozone corrected ECC data was used. All flights were analyzed in the old lower-resolution format in order to avoid possible biases that might be introduced by the switch to higher resolution digital sondes in the mid-1990s.

\section{Results and discussion}

Table 1 shows the number of soundings indicating surface depletion, as well as the total number of soundings (in parentheses) at each station. As anticipated from long-term surface measurements (Oltmans and Kohmyr, 1986; Anlauf et 

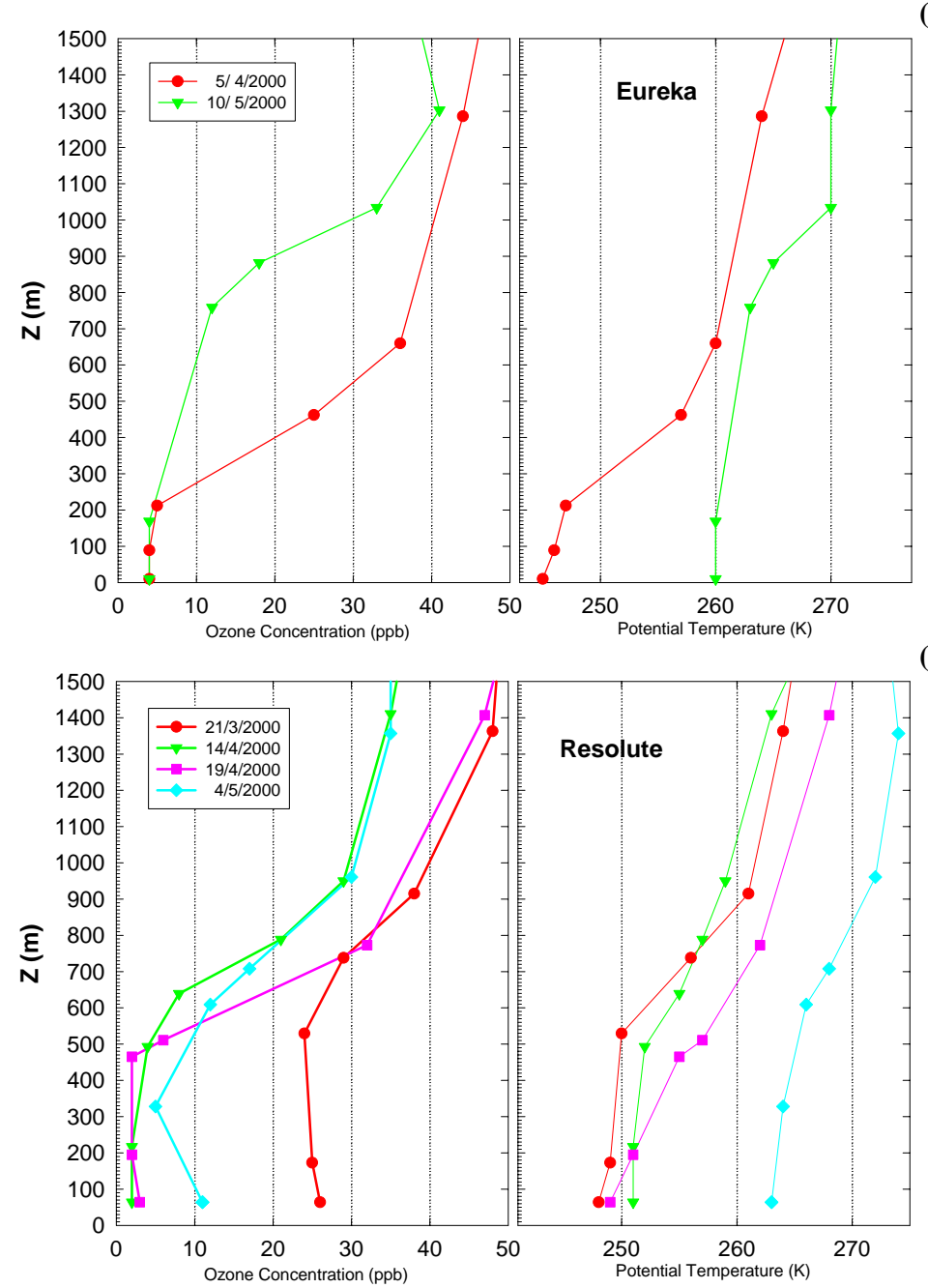

(b)

(a)

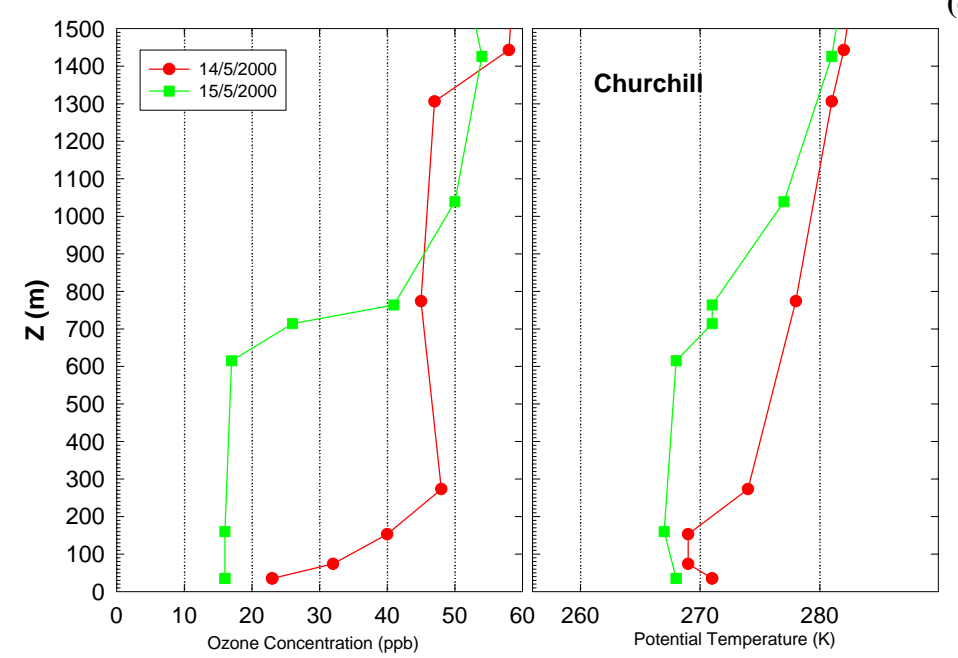

(c)

Fig. 2. (a) As Fig. 1a, in old (compressed) data format. (b) As Fig. 1b, in old (compressed) data format. (c) As Fig. 1c, in old (compressed) data format. Although the nominal resolution of the profiles is less than that of Fig. 1, the effective resolution is clearly adequate to identify both the degree of depletion and the vertical extent of the depleted layer and the accompanying temperature inversion. 
Table 1. Number of soundings indicating surface depletion $(<10 \mathrm{ppbv})$ events in the historical ozonesonde record, grouped by season. The number in brackets is the total number of soundings in each period. Data up to the end of 2000 have been included. Canadian data are shown separately for the pre-1980 (BM) period and for the last two decades (ECC)

\begin{tabular}{l|cccc|cccc}
\hline Station & \multicolumn{4}{|c|}{ ECC } & \multicolumn{4}{c}{ Brewer-Mast } \\
\hline & DJF & MAM & JJA & SON & DJF & MAM & JJA & SON \\
\hline \multirow{3}{*}{ Resolute } & $0(250)$ & $64(207)$ & $5(146)$ & $1(150)$ & - & - & - & - \\
Eureka & $6(246)$ & $61(225)$ & $7(190)$ & $3(189)$ & $1(142)$ & $22(166)$ & $9(150)$ & $1(141)$ \\
Churchill & $1(264)$ & $28(139)$ & $1(96)$ & $0(105)$ & - & - & - & - \\
Goose Bay & $2(222)$ & $8(240)$ & $3(218)$ & $1(194)$ & $1(62)$ & $1(57)$ & $12(69)$ & $5(62)$ \\
Edmonton & $2(237)$ & $2(239)$ & $19(226)$ & $20(221)$ & $4(134)$ & $1(117)$ & $16(123)$ & $15(122)$ \\
Ny-Ålesund & $24(222)$ & $6(239)$ & $9(225)$ & $15(203)$ & $7(86)$ & $1(83)$ & $2(81)$ & $4(82)$ \\
Neumayer & $7(163)$ & $1(126)$ & $1(170)$ & $7(246)$ & - & - & - & - \\
Marambio & $7(48)$ & $0(23)$ & $1(92)$ & $5(167)$ & - & - & - & -
\end{tabular}

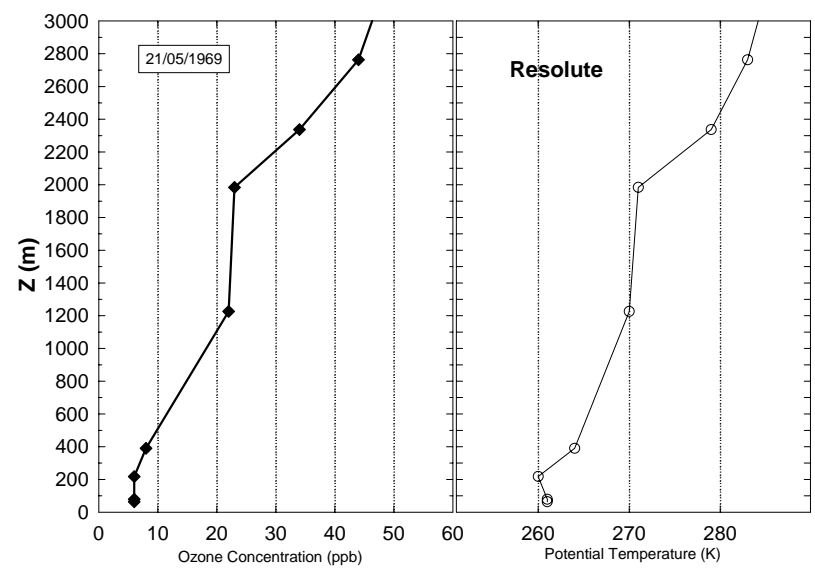

Fig. 3. A surface ozone depletion event at Resolute: 21 May 1969. Despite the poorer quality of the older Brewer-Mast soundings, the event is clearly shown.

al., 1999), which show depletion events in the Arctic to be mostly confined to the March-May period, there are relatively few soundings outside this period indicating surface depletion at Alert, Eureka or Resolute. There are, however, relatively few surface depletion episodes altogether at Churchill, which is surprising, given its central location with respect to the large area of enhanced $\mathrm{BrO}$ observed by GOME. Similar remarks may be made for Ny-Ålesund, Marambio and Neumayer. At the two Antarctic stations a surprising number of soundings in the December-February period (summer) indicate surface depletion. Comparison of these profiles with those indicating surface depletion in the September-November period showed that in almost every case the summer soundings indicated low ozone throughout the lower and middle troposphere, while the spring soundings demonstrated the characteristic sharp ozone recovery at

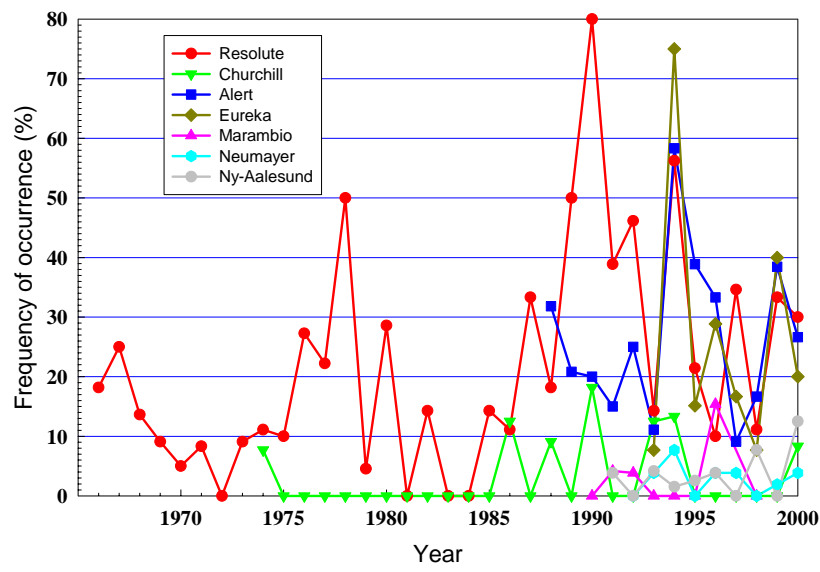

Fig. 4. Frequency of occurrence of surface ozone $(<10 \mathrm{ppbv}) \mathrm{de}-$ pletion events at selected ozonesonde stations, 1966-2000. Data have been adjusted for the effects of occasional irregular sampling.

modest altitude. Ozone soundings at Edmonton and Goose Bay were also examined. These stations are far from polar ice, and would not be subject to Br-induced depletion. While a few soundings indicate surface depletion at these sites during the March-May period, unlike the other sites, there are a large number outside this period. This suggests that these depletion episodes, including those during the March-May period, are actually due to local pollution events (NO titration).

The older BM soundings show a seasonal pattern similar to that for the ECC soundings, with the caveat that the Canadian BM sondes were less reliable in the troposphere. Laboratory work has shown that preparation methods employed in the 1960s and 1970s for these instruments tended to produce tropospheric values that were about $15 \%$ low on average (Tarasick et al., 2002), while the overall response 
shows considerably more variation than is the case for the ECC sondes. They also appear to have suffered a greater frequency of sonde malfunction. These factors may account for the somewhat larger number of soundings indicating surface depletion outside of the March-May period in the Churchill $\mathrm{BM}$ record. Unfortunately there are no older data for Alert or Eureka.

Since depletion episodes can on occasion persist for several days (Bottenheim et al., 2002), this may introduce some autocorrelation in the time series, particularly for Eureka and Alert, where sondes are often launched more frequently than once per week. In order to properly estimate the frequency of depletions at Alert and other stations, soundings were grouped by week, over the 13-week period from Julian day 61 through 151 (244 through 334 for the Antarctic stations), and the 13 weekly frequencies were averaged to find an overall average for each year. The results of this exercise are shown in Fig. 4.

One observation that may be made immediately is that depletion events have been occurring regularly in the Canadian Arctic at least since 1966, when regular ozone soundings began. This is consistent with evidence from other sources that the depletions are caused by naturally produced $\mathrm{Br}$ (Barrie and Platt, 1997). It is also evident that there is some correlation between the frequency observed at Alert, Eureka and Resolute, for the period of simultaneous records. This is suggestive of a common meteorological influence, such as the frequency or strength of boundary layer temperature inversions. In addition, despite its high variability, there is an evident increase of the frequency of occurrence at Resolute. Over the 35-year period 1966-2000 the linear trend is $0.66 \pm 0.59 \%$ per year (95\% confidence limits). This trend is quite robust: a weighted regression (taking into account the slightly different number of weeks of soundings each year) gives a somewhat larger trend; treating the peak values of 1989-1991 as outliers and either simply omitting them or replacing them with the lower frequencies observed in the same years at Alert produces somewhat smaller trends; in all cases, however, trends are still significant at the 95\% level. If only the ECC data (1980-2000) are considered, the linear trend is $1.03 \pm 1.51 \%$ per year. Churchill and Alert, with shorter records, also show smaller, positive but nonsignificant trends: $0.14 \pm 0.28 \%$ and $0.39 \pm 2.31 \%$ per year.

The observation of an increasing trend in the occurrence of ozone depletion events can explain the record of mercury in Arctic biota which has been increasing over the last few decades (Lindberg et al., 2002, and references therein). Measurements of gaseous elementary mercury (GEM) in the Arctic atmosphere have revealed strong depletion episodes that show a remarkable positive correlation with ozone depletion events (Schroeder et al., 1998). Similar to ozone, the depletion of GEM is therefore thought to be initiated by oxidation due to bromine atoms, and it has been postulated that the products of this process will be readily deposited to the surface (Lu et al., 2001; Lindberg et al., 2002). If the key to
GEM depletion is the presence of reactive bromine, which can only be sustained via $\mathrm{BrO}_{\mathrm{x}}$ recycling and hence ozone depletion (see below), the increase of mercury in Arctic biota is a direct result of the increase in occurrence of ozone depletion episodes.

It is interesting to consider the possible causes of such an increase in the frequency of depletion events. The principal chemistry that leads to ozone destruction at polar sunrise can be summarized by the following reaction scheme:

a. gas phase:

$$
\begin{aligned}
& \mathrm{Br}+\mathrm{O}_{3} \rightarrow \mathrm{BrO}+\mathrm{O}_{2} \\
& \mathrm{BrO}+\mathrm{BrO} \rightarrow \mathrm{Br}_{2}+\mathrm{O}_{2} \\
& \mathrm{BrO}+\mathrm{HO}_{2} \rightarrow \mathrm{HOBr}+\mathrm{O}_{2} \\
& \mathrm{Br}+h \nu \rightarrow 2 \mathrm{Br} \\
& \mathrm{Br}+\mathrm{RH} \rightarrow \mathrm{HBr}+\mathrm{R} \\
& \text { b. condensed phase: }
\end{aligned}
$$

$\mathrm{HOBr}+\mathrm{Cl}^{-}+\mathrm{H}^{+} \rightarrow \mathrm{BrCl}+\mathrm{H}_{2} \mathrm{O}$

$\mathrm{BrCl}+\mathrm{Br}^{-} \rightarrow \mathrm{Br}_{2}+\mathrm{Cl}^{-}$

where RH is one of several hydrocarbon species. The rapid loss of ozone in the gas phase will be possible as long as the $\mathrm{BrO}_{\mathrm{x}}$ (reactive bromine, $\mathrm{Br}+\mathrm{BrO}$ ) mixing ratio can be sustained at high levels; in the atmosphere reactions such as (5) which convert $\mathrm{BrO}_{\mathrm{x}}$ to the unreactive $\mathrm{Br}^{-}$(bromide) form will prevent this from happening. The key to the ozone destruction process in the Arctic boundary layer is therefore thought to be the occurrence of heterogenous reactions in the condensed phase on the surfaces of aerosols or surface snow and ice (Fan and Jacob, 1992; Tang and McConnell, 1996) as summarized in reactions (6) and (7), leading to the socalled "bromine explosion". Sea salt bromine is considered the most likely source of this bromine, and indeed $\mathrm{Br}_{2}$ production in Arctic snow has recently been confirmed (Foster et al., 2001).

Boundary layer meteorological conditions will affect the rates of some of the above processes in several ways; for example, greater atmospheric stability would lead to less mixing of ozone-rich air from above; temperature or wind changes could lead to more frequent open leads in sea ice and therefore more saline ice crystals laden with bromide. We examined time series of average temperature inversion strengths (defined as $T_{1000}-T_{S}$, the difference between the temperature at $1000 \mathrm{~m}$ and that at the surface), surface temperatures and surface winds, as well the variability in each, for the spring period at Resolute. No correlation with the frequency of depletion events was found. However, over the 35 -year record, surface temperatures and temperature inversion strengths did show a trend. The average strength of temperature inversions was found to be decreasing, (i.e. implying less atmospheric stability) both at Resolute and Churchill (while increasing dramatically at Alert). This is primarily due to an increase in surface temperatures both at Resolute 
Table 2. Columns 3 and 4: Average frequency of occurrence of surface ozone depletion events at polar stations over the period 1991-2000. Column 5: Average springtime surface temperatures $(\bar{T})$. Column 6: Average surface temperatures $(\bar{T})$ during depletion episodes. Column 7: Difference between springtime surface temperature and that at $1000 \mathrm{~m}\left(\overline{T_{1000}-T_{S}}\right)$. Data have been adjusted for the effects of occasional irregular sampling. Temperature averages are for the entire record in each case

\begin{tabular}{|c|c|c|c|c|c|c|}
\hline \multirow[t]{2}{*}{ Station } & \multirow[t]{2}{*}{ Latitude } & \multicolumn{2}{|c|}{ Adjusted frequency (\%) } & \multirow[t]{2}{*}{$\bar{T}\left({ }^{\circ} \mathrm{C}\right)$} & \multirow[t]{2}{*}{$\bar{T}(D E)\left({ }^{\circ} \mathrm{C}\right)$} & \multirow[t]{2}{*}{$\overline{T_{1000}-T_{S}}\left({ }^{\circ} \mathrm{C}\right)$} \\
\hline & & $<10 \mathrm{ppbv}$ & $<20 \mathrm{ppbv}$ & & & \\
\hline Alert & $83 \mathrm{~N}$ & 27.3 & 41.1 & -21.9 & -19.6 & 3.9 \\
\hline Resolute & $75 \mathrm{~N}$ & 29.6 & 51.5 & -21.9 & -23.5 & 4.0 \\
\hline Eureka & $80 \mathrm{~N}$ & 26.4 & 41.7 & -24.3 & -24.4 & 6.4 \\
\hline Churchill & $59 \mathrm{~N}$ & 3.4 & 16.6 & -11.5 & -17.1 & 3.0 \\
\hline $\mathrm{Ny}-$ Ålesund & $79 \mathrm{~N}$ & 3.2 & 12.0 & -7.8 & -9.9 & -3.8 \\
\hline Neumayer & $71 \mathrm{~S}$ & 2.8 & 32.5 & -17.4 & -18.8 & 1.3 \\
\hline Marambio & $64 \mathrm{~S}$ & 3.3 & 28.9 & -6.3 & -9.2 & -2.8 \\
\hline
\end{tabular}

$\left(0.17 \pm 0.08^{\circ} \mathrm{C}\right.$ per year $)$ and Churchill $\left(0.22 \pm 0.18^{\circ} \mathrm{C}\right.$ per year), and a decrease at Alert.

The lack of a direct observed correlation with meteorological variables does not necessarily rule out the possibility that the increase in frequency of depletion events in Fig. 4 is related to meteorological changes, since there is considerable evidence that long-range transport plays a major role in surface depletions (Bottenheim et al., 1990; Barrie and Platt, 1997). Thus, the meteorological conditions at the actual measurement site are by no means indicative of the conditions upstream where the bulk of the depletion chemistry may have occurred. Moreover, as we suggest below, several competing meteorological effects may be involved; the frequency of occurrence of open leads in the ice pack has probably increased with surface warming (Dickson, 1999; McPhee et al., 1998), while the actual depletion process may be favoured by cold surface temperatures and the consequent greater atmospheric stability. In fact, the average temperature during depletion events (Table 2) is lower at Churchill, Ny-Ålesund, Neumayer and Marambio, implying that depletion events are associated with colder than average surface temperatures, and/or that at these stations severe depletions may be a result of transport from higher latitudes, as found by Hoenniger et al. (2002).

Table 2 compares the average frequency of springtime depletions (calculated as in Fig. 4) over the period 1990-2000 for the seven polar stations, as well as average surface temperatures $(\bar{T})$ and average strength of boundary layer temperature inversions $\left(\overline{T_{1000}-T_{s}}\right)$. The average frequency of springtime depletions below $20 \mathrm{ppb}$ is also shown. Since this criterion admits more (partial) depletion events it provides better statistics but (incorrectly) identifies as depletion events many soundings in the summer. It will be evident that the stations divide into two groups. For Alert, Resolute and Eureka, severe $(<10 \mathrm{ppb})$ depletion episodes are common, and average springtime surface temperatures are below $-20^{\circ} \mathrm{C}$, while for Churchill, $\mathrm{Ny}-$ Ålesund, Neumayer and Marambio, episodes of severe surface ozone depletion are infrequent, and average springtime surface temperatures are above $-20^{\circ} \mathrm{C}$. Temperature inversions are also stronger at the stations in the first group, indicating more stable surface air masses. Comparison of the frequencies of episodes below $20 \mathrm{ppb}$ with those for severe depletion episodes shows that while the latter are common only at the three Canadian Arctic stations, partial (10-20 ppb) depletions are relatively common at all stations examined. Average surface temperatures during (severe) depletion events are also shown; with the caveat that these have large standard errors due to the small number of data points in each average, it is notable that for Churchill, Ny-Ålesund, Neumayer and Marambio they are much colder than the corresponding overall seasonal average, reinforcing the notion that colder temperatures may be required for ozone depletions to occur.

The apparent division on the basis of average springtime surface temperature is intriguing: surface temperatures below about $-20^{\circ} \mathrm{C}$ seem to be required for the occurrence of severe ozone depletion episodes. It is conceivable that this is a reflection of the nature of the overall mechanism that drives reaction (6). While seasalt aerosols surfaces may be treated as liquids (Koop et al., 2000), Michalovsky et al. (2000) have shown that aerosol chemistry alone cannot explain the required efficient $\mathrm{BrO}_{\mathrm{x}}$ cycle, and that the occurrence of chemical reactions on surface snow and ice are critical. Adams et al. (2002) have recently reported that the uptake of $\mathrm{HOBr}$ on frozen $\mathrm{NaCl} / \mathrm{NaBr}$ surfaces is very efficient below $-21^{\circ} \mathrm{C}$, the $\mathrm{NaCl} \cdot 2 \mathrm{H}_{2} \mathrm{O}$ eutectic point, and that under realistic ambient conditions such uptake will predominantly produce $\mathrm{Br}_{2}$ molecules. However, as pointed out by these authors, a complication is the presence of the illdefined liquid layer (the so-called quasi-liquid layer or QLL) coating ambient snow and ice surfaces. As noted by Koop et al. (2000) and Roscoe (2002), seasalt deposited on ice will 
have remaining liquid down to much lower temperatures than $-21^{\circ} \mathrm{C}$. Cho et al. (in press, 2002) argue that under the high ionic strength conditions applicable to Arctic ocean surface conditions the QLL should be considered a quasi-brine layer (QBL). Below the $\mathrm{NaCl} \cdot 2 \mathrm{H}_{2} \mathrm{O}$ eutectic point this QBL is calculated to be highly acidic, a key requirement for reaction (6) to be efficient (Adams et al., 2002). Koop et al. (2000) calculate that the molality of halogen ions in such a QBL will drastically increase with lower temperature, and that especially the $\mathrm{Br}^{-}$concentration will increase when the temperature drops below $-21^{\circ} \mathrm{C}$, as $\mathrm{NaCl} \cdot 2 \mathrm{H}_{2} \mathrm{O}$ precipitates. A further complication is that it is highly unlikely that liquid phase thermodynamics and kinetics are applicable for reaction (6) in the QBL (see, e.g. Dominé et al., 1995). Clearly there is evidence to suggest that low temperatures may favor reaction (6), but a definitive picture is lacking at this time.

Another factor that should be considered in the air-snow interaction is the aerodynamic resistance that has to be overcome by an $\mathrm{HOBr}$ molecule to reach the surface on which reaction (6) will occur. The Arctic boundary layer is generally highly stably stratified and consequently this aerodynamic resistance is large, and may well be the rate-limiting factor (see, e.g. Huff and Abbott, 2000). A large surface area would increase the efficiency of the overall process. In this respect it is interesting to speculate on the importance of the formation of "frost flowers": fragile, often highly saline ice crystals that are a common surface feature of new sea ice forming on open leads (e.g. Perovich and Richter-Menge, 1994). Martin et al. (1996) have observed from laboratory experiments that the rate of frost flower growth increases substantially with a decrease in surface temperature. In his comments to our original manuscript, Roscoe (2002) proposes that it may take 2 to 3 days for frost flowers to form below $-20^{\circ} \mathrm{C}$, but longer at higher temperatures, and that this timing of frost flower production is critical. Both Martin et al. (1996) and Perovich and Richter-Menge (1994) also observed that the actual crystal structure of the flowers was different when growing at temperatures above (dendritic) or below (rod like) about $-20^{\circ} \mathrm{C}$. Combined with the expectation that as the temperature drops below $-21^{\circ} \mathrm{C}$ the molality of $\mathrm{Br}^{-}$at the surface will increase, the importance of frost flowers as a medium for reaction (6) should increase substantially below about $-20^{\circ} \mathrm{C}$.

Interestingly, frost flowers are usually associated with freezing over of open leads in the ice pack. As speculated by Roscoe (2002) (see also Roscoe et al., 2001), the occurrence of open leads in the ice pack has likely increased due to the increase in greenhouse gases (Dickson, 1999; McPhee et al., 1998). Hence an increased production of frost flowers may have occurred, which would explain the observed increase in the frequency of occurrence of severe ozone depletion episodes we have derived from the Resolute record. Lindberg et al. (2002) similarly hypothesize that a warming climate is responsible for the increase in mercury in Arctic biota, which as we have indicated above should imply an increase in ozone depletion event occurrence.

\section{Conclusions}

An examination of the historical ozonesonde record shows that severe boundary-layer depletion events occur frequently at Alert, Eureka and Resolute in Canada, but infrequently at Churchill, and at other stations in the Arctic and Antarctic. These differences appear to be related to differences in average springtime surface temperatures. Temperature profiles near polar sunrise at the three Canadian high Arctic stations are characterized by strong surface temperature inversions and cold (below $-20^{\circ} \mathrm{C}$ ) surface temperatures, in contrast to the other stations. However, little correlation is observed between these temperature conditions and the frequency of occurrence of depletion events, as these may be a result of non-local chemical destruction and transport. The frequency of occurrence of boundary-layer ozone depletion episodes is found to be increasing, particularly at Resolute (the only site with a sufficiently long record for proper trend analysis), explaining the increase in mercury levels in Arctic biota over the last few decades. As cold $\left(\sim-20^{\circ} \mathrm{C}\right)$ surface temperatures appear to be a necessary condition for the production of depletion episodes, we speculate that this may be related to a more efficient heterogeneous reaction converting bromide to bromine on saline ice crystals. In addition, we propose that the formation of "frost flowers" on new sea ice, which is known to occur more efficiently at lower temperatures, may provide the required saline ice surfaces. The increase in frequency of boundary layer ozone depletion events can then be understood in light of the increase in open leads in the Arctic ice cover due to the increase in greenhouse gas levels.

Acknowledgements. All data presented here were supplied by the World Ozone and UV Data Centre in Canada. Some additional data (for Thule, Scoresbysund, Bear Island and Ny-Ålesund) was supplied by the NADIR data centre in Norway. We thank the many observers who obtained these data over many years of careful work. We also thank P. von der Gathen, H. Gernandt, I. S. Mikkelsen, J. Davies and E. Hare for assistance with the data and for helpful suggestions, and J. Abbatt (University of Toronto), P. B. Shepson (Purdue University), J. Fuentes (University of Virginia), C. T. McElroy, W. H. Schroeder and D. I. Wardle (MSC), and the reviewers of our original manuscript (H. Roscoe and an anonymous referee) for stimulating comments and discussions.

\section{References}

Anlauf, K. G., Mickle, R. E., and Trivett, N. B. A.: Measurement of ozone during Polar Sunrise Experiment 1992, J. Geophys. Res., 99, 25 345-25 353, 1994.

Anlauf, K. G., Hayden, K. L., Fioletov, V., and Watt., M. F.: "Ground-level ozone in High Arctic Canada", presented at the 6th Scientific Conference of the International Global Atmospheric Chemistry Project (IGAC), 13-17 Sept., Bologna, Italy, 1999.

Barrie, L. A., Bottenheim, J. W., Schnell, R. C., Crutzen, P. J., and Rasmussen, R. A.: Ozone destruction and photochemical reac- 
tions at polar sunrise in the lower Arctic atmosphere, Nature, 334, 138-141, 1988.

Barrie, L. and Platt, U.: Arctic tropospheric chemistry: an overview, Tellus, 49B, 450-454, 1997.

Bottenheim, J. W., Gallant, A. G., and Brice, K. A.: Measurements of NOY species and $\mathrm{O}_{3}$ at $82^{\circ} \mathrm{N}$ latitude, Geophys. Res. Lett., 13, 113-116, 1986.

Bottenheim, J. W., Barrie, L. A., Atlas, E., Heidt, L. E., Niki, H., Rasmussen, R. A., and Shepson, P. B.: Depletion of lower tropospheric ozone during Arctic spring: the Polar Sunrise Experiment 1988, J. Geophys. Res., 95, 101-127, 1990.

Bottenheim, J. W., Fuentes, J. D., Tarasick, D. W., and Anlauf K. G.: Ozone in the Arctic lower troposphere during winter and spring 2000 (ALERT2000), Atmospheric Environment, 36, 2535-2544, 2002.

Cho, H., Shepson, P. B., Barrie, L. A., Cowin, J. P., and Zaweri, R.: NMR investigation of the Quasi-Brine Layer in ice/brine mixtures, J. Phys. Chem., in press, 2002.

Dickson, R. R.: All change in the Arctic, Nature, 397, 389-391, 1999.

Domine F., Thibert E., Silvente E., Legrand M., and Jaffrezo J.-L.: Determining past atmospheric $\mathrm{HCl}$ mixing ratios from ice-core analyses, J. Atmos. Chem., 21, 165-186, 1995.

Fan, S-M. and Jacob, D. J.: Surface ozone depletion in Arctic spring sustained by bromine reactions on aerosols, Nature, 359, 522524, 1992.

Foster, K. L., Plastridge, R. A., Bottenheim, J. A., Shepson, P. B., Finlayson-Pitts, B. J., and Spicer, C. W.: The role of Br2 and $\mathrm{BrCl}$ in surface ozone destruction at polar sunrise, Science, 291, 471-474, 2001

Hoenninger, G., Leser, H., Sebastian, O., and Platt, U.: "Day and nighttime chemistry of bromine oxide: first measurements at the Hudson Bay and comparison with model simulations", Geophysical Research Abstracts 4, 27th General Assembly of EGS, abstract EGS02-A-01400 and oral presentation OA20.04-1EW1A005, 2002

Huff, A. K. and Abbatt J. P. D.: Gas-phase Br2 production in heterogeneous reactions of $\mathrm{Cl}_{2}, \mathrm{HOCl}$ and $\mathrm{BrCl}$ with halide-ice surfaces, J. Phys. Chem. A, 104, 7284-7293, 2000.

Koop, T., Kapilashrami, A., Molina, L. T., and Molina, M. J.: Phase transitions of sea-salt/water mixtures at low temperatures: Implications for ozone chemistry in the polar marine boundary layer, J. Geophys. Res., 105D, 26393-26 402, 2000.

Lindberg, S. E., Brooks, S., Lin, C. J., Scott, K. J., Landis, M. S., Stevens, R. K., Goodsite, M., and Richter, A.: Dynamic oxidation of gaseous mercury in the Arctic troposphere at Polar sunrise, Environ. Sci. Technol., 36, 1245-1256, 2002.

Lu, J. Y., Schroeder, W. H., Barrie, L. A., Steffen, A., Welch, H. E., Martin, K., Lockhart, L., Hunt, R. V., Boila, G., and Richter, A.: Magnification of atmospheric mercury deposition to polar regions in springtime: the link to tropospheric ozone depletion chemistry, Geophys. Res. Lett., 28, 3219-3222, 2001.

Martin, S., Yu, Y., and Drucker, R.: The temperature dependence of frost flower growth on laboratory sea ice and the effect of the flowers on infrared observations of the surface, J. Geophys. Res., 101, 12 111-12 125, 1996.

McElroy, C. T., McLinden, C. A., and McConnell, J. C.: Evidence for bromine monoxide in the free troposphere during the Arctic polar sunrise, Nature, 397, 338-340, 1999.

McPhee, M. G., Stanton, T. P., Morison, J. H., and Martinson, D.G.: Freshening of the upper ocean in the Arctic: Is perennial sea ice disappearing? Geophys. Res. Lett., 25, 1729-1732, 1998.

Michalovski, B., Francisco, J. S., Li, Y., Li, S.-M., Barrie, L. A., Bottenheim, J. W., and Shepson, P. B.: A computer model study of multiphase chemistry in the Arctic boujndary layer during polar sunrise, J. Geophys. Res., 105D, 15 131-15 146, 2000.

Miller, H. L., Weaver, A., Sanders, R. W., Arpag, K., and Solomon, S.: Measurements of arctic sunrise surface ozone depletion events at Kangerlussuaq, Greenland, Tellus, 49B, 496-509, 1997.

Murayama, S., Nakazawa, T., Tanaka, M., Aoki, S., and Kawaguchi, S.: Variations of tropospheric ozone concentration over Syowa station, Antarctica, Tellus, 44B, 262-272, 1992.

Oltmans, S. J. and Komhyr, W. D.: Surface ozone distributions and variations from 1973-1984 measurements at the NOAA Geophysical Monitoring For Climatic Change baseline observatories, J. Geophys. Res., 91, 5229-5236, 1986.

Rasmussen, A., Kiilsholm, S., Havskov Sørensen, J., and Steen Mikkelsen, I.: Analysis of tropospheric ozone measurements in Greenland, Tellus, 49B, 510-521, 1997.

Richter, A., Wittrock, F., Eisinger, M., and Burrows, J. P.: GOME observations of tropospheric $\mathrm{BrO}$ in northern hemispheric spring and summer 1997, Geophys. Res. Lett., 25, 2863-2686, 1998.

Roscoe, H. K., Kreher, K., and Friess, U.: Ozone loss episodes in the free Antarctic troposphere, suggesting a possible climate feedback, Geophys. Res. Lett., 28, 2911-2914, 2001.

Roscoe, H. K.: Interactive comment on "Surface ozone depletion episodes in the Arctic and Antarctic from historical ozonesonde records", Atmos. Chem. Phys. Discuss., 2, S84-S90, 2002.

Schroeder, W. H., Anlauf, K. G., Barrie, L. A., Lu, J. Y., Steffen, A., Schneeberger, D. R., Berg, T.: Arctic springtime depletion of mercury, Nature, 394, 331-332, 1998.

Solberg, S., Schmidtbauer, N., Semb, A., and Stordal, F.: Boundary-layer ozone depletion as seen in the Norwegian Arctic in spring, J. Atmos. Chem., 23, 301-332, 1996.

Taalas, P., Kyrö, E., Supperi, A., Tafuri, V., and Ginzburg, M.: Vertical distribution of tropospheric ozone in Antarctica and in the European Arctic, Tellus, 45B, 106-109, 1993.

Tang, T. and McConnell, J. C.: Autocatalytic release of bromine from arctic snow pack during polar sunrise, Geophys. Res. Lett., 23, 2633-2636, 1996.

Tarasick, D. W., Kerr, J. B., Wardle, D. I., Bellefleur, J. J., and Davies, J.: Tropospheric ozone trends over Canada: 1980-1993, Geophys. Res. Lett., 22, 409-412, 1995.

Tarasick, D. W., Davies, J., Anlauf, K., Watt, M., Steinbrecht, W., and Claude, H. J.: Laboratory investigations of the response of Brewer-Mast sondes to tropospheric ozone, J. Geophys. Res., in press, 2002.

Wagner, T. and Platt, U.: Satellite mapping of enhanced BrO concentrations in the troposphere, Nature, 395, 486-490, 1998.

Wessel, S., Aoki, S., Winkler, P., Weller, R., Herber, A., Gernandt, H., and Schrems, O.: Tropospheric ozone depletion in polar regions: A comparison of observations in the Arctic and Antarctic, Tellus, 50B, 34-50, 1998. 